\title{
LOKAL WISDOM DAN NARASI KEBEBASAN BERAGAMA BAGI PENGHAYAT ABOGE (ALIF REBO WAGE)
}

NARASI LAPORAN PENELITIAN LAPANGANPENGHAYAT KEPERCAYAAN LOKAL

13/354242/PMU/07820 


\section{PENGANTAR}

Tulisan ini merupakan sebuah narasi catatan penelitian lapangan yang peneliti dapatkan setelah melakukan penelitian terkait penghayat kepercayaan aboge di Mojokerto. Penelitian ini dilaksanakan di area kabupaten Mojokerto dan Sidoarjo tepatnya di 4 titik lokasi yaitu di kecamatan Kutorejo, Dlanggu, Trawas dan Tanggulangin kabupaten Sidoarjo. Keempat lokasi tersebut merupakan tempat dimana peneliti bertemu dengan informan. Penelitian ini dilaksanakan sejak februari sampai dengan april pada 2015. Lamanya masa penelitian disebabkan beberapa informan tidak mudah untuk ditemui. Salah satu misalnya adalah mbah Khusyen. Mbah khusen merupakan salah satu informan dari penelitian ini. beliau tidak tinggal dipemukiman warga melainkan di goa yang berada di wilayah perhutani. Goa tersebut bernama goa putih atau goa anoman, berada di dusun tengkep desa jati jejer kecamatan trawas. Mbah khusyen sudah tinggal di goa tersebut selama 22 tahun dan beliau juga merupakan penghayat yang mengabdikan dirinya kepada sang hyang demi mengamalkan ilmu kejawen. Informan lainnya adalah cak mundir, penghayat aboge. Cak mundir kelahiran mojokerto namun seringkali melalang buana. Peneliti kebetulan merupakan saudara dekat dengan informan sehingga tidak terlalu sulit untuk bertemu dengan cak mundir. Peneliti bertemu cak mundir di Tanggulangin Sidoarjo. Informan selanjutnya adalah mas jaka. Mas jaka merupakan salah satu penghayat dari aliran penghayat Roso Sejati. Pertemuan peneliti dengan mas jaka karena mendapat informasi dari cak andim, termasuk salah satu informan di penelitin ini. mas jaka tinggal di desa ngembeh kecamatan dlanggu. Saat itu, beliau bekerja sebagai satpam di salah satu pabrik di Kutorejo. Beliau mengikuti ajaran aliran roso sejati sudah lama dan mempunyai banyak pengetahuan terkait dengan ilmu kejawen. Selain dari 4 informan tersebut, banyak juga informan-informan lain yang tidak dapat peneliti tuliskan dalam catatan kaki ini. Total terdapat sekitar 12 informan yang peneliti temukan. Meskipun beberapa informan bukanlah penghayat Aboge namun menurut keterangan cak mundir Aboge bukanlah sebuah nama untuk kelompok tertentu melainkan sebuah istilah yang disematkan kepada orang yang mendalami atau memahami tentang teologi jawa baik secara hakikat keilmuan, filosofi dan prilakunya. 


\section{MEMPERKENALKAN PENGHAYAT ABOGE (Alif Rebo Wage)}

Aboge adalah sebuah istilah yang disematkan kepada orang yang mendalami atau memahami tentang teologi jawa baik secara hakikat keilmuan, filosofi dan prilakunya. ${ }^{1}$ Orang yang mendalami ilmu hakikat pada dasarnya adalah mereka-mereka yang sudah tidak berada dalam level orang awam yang hanya tahu akan hal-hal yang sifatnya duniawi. Mereka lebih cenderung untuk mendekatkan diri atau lebih mengenal yang hakiki dalam artian pendekatan kearah ketuhanan atau yang biasa disebut sebagai kebenaran sejati. Kata Aboge sendiri mempunyai beberapa pengertian, jikalau dirujukkan pada pengertian secara harfiyah maka, kata Aboge itu sendiri merujuk pada kalender Jawa.

Dalam pemahaman orang Jawa kata Aboge itu terdiri dari tiga suku kata yaitu "alip", "rebo" dan "wage". Alip merujuk pada sebuah nama dari tahun Jawa, rebo merujuk pada hari dalam satu wuku (minggu) yaitu rabu, sedangkan wage merujuk pada nama hari pasaran dalam kalender Jawa. Jika dianalisis secara mendalam mengenai hal tersebut, pada dasarnya orang yang mendalami ilmu kejawen atau filosofi jawa mempunyai pemahaman sendiri terkait dengan kalenderisasi dan kalender tersebut cenderung berbeda dengan kalender masa kini. Sebagai contohnya penamaan dalam tahun Jawa, terdapat delapan nama tahun Jawa yaitu "Alip, Ehe, Jinawal, Je, Dal, Be, Wawu, dan Jumakir". Sedangkan untuk nama hari dalam kurun waktu satu minggu istilah-istilah yang digunakan masih sama seperti kalender masa kini dan juga nama hari pasaran yaitu "Legi, Pahing, Pon, Wage dan Kliwon".

Pemakaian nama dalam kalender Jawa bukan semata-mata tanpa ada alasan. Nama dalam kalender tersebut diperuntukkan untuk menghitung setiap kejadian dalam tiap detik, menit, jam, hari, bulan dan tahun selain itu nama-nama tersebut juga menunjukkan sebuah angka-angka tertentu. Alasan penggunaan kalender-kalender tersebut adalah karena dalam pandangan orang Jawa, kehidupan manusia merupakan satu kesatuan dengan alam semesta dan peristiwa-peristiwa yang menimpa manusia bukanlah sebuah kebetulan, melainkan sudah ditentukan oleh tuhan. Oleh karena itu, orang Jawa dengan cara memperhatikan setiap kejadian-kejadian yang berulang tersebut, mencoba untuk membuka tabir tuhan dengan cara memberikan tanda-tanda dari nama kalender tersebut.

\footnotetext{
${ }^{1}$ Wawancara dengan Cak Mundir, Jabon Mojokerto, dirumahnya, pada pukul 19.00, tanggal 09-07-2015

${ }^{2}$ Aditya, Dedy Yusuf. "Eksplorasi unsur matematika dalam kebudayaan masyarakat jawa." Formatif: Jurnal Ilmiah Pendidikan MIPA 7.3 (2018).
} 
Dalam hal ini, jika kata Aboge diartikan secara gamblang maka kata tersebut merujuk pada kalenderisasi Jawa seperti yang sudah dijelaskan di atas, akan tetapi, jika Aboge diartikan secara maknawiyah maka kata itu sendiri pada dasarnya merujuk pada orang-orang yang mendalami ilmu hakikat yang mempunyai makna orang yang sudah menemukan keimanannya. Orang yang sudah menemukan keimanannya di sini diartikan sebagai orang yang sudah menemukan kebenaran sejati dalam kehidupannya atau orang yang mengetahui jati diri kemanusiaannya. Terdapat kalimat yang sering digunakan oleh orang Jawa dalam hal tersebut "Manunggling kawulo gusti" yaitu bersatunya dzat manusia dengan dzat tuhan. Kalimat tersebut menjadi dasar pedoman bagi orang Jawa dalam mempelajari ilmu hakikat dan praktek-praktek kejawennya.

Istilah Aboge juga bias dirujukkan kepada semua orang, dalam artian orang yang sudah mencapai tahapan-tahapan tertentu dalam hal spiritualitasnya bias dikatakan sebagai Aboge. Oleh karena itu, kata Aboge pada hakikatnya merujuk pada sebuah tingkatan yang mana jika orang tersebut sudah mencapai suatu tingkatan tertentu maka dia bias dikatakan sebagai Aboge. Jika diartikan, istilah Aboge disini bukanlah merujuk pada satu golongan tertentu atau hanya untuk satu golongan saja akan tetapi merujuk pada semua orang di dunia ini.

Kebanyakan orang mungkin tidak tahu bahkan tidak mengerti bahwasanya orang yang sudah mencapai tingkat spiritualitas tertentu bias dikatakan sebagai Aboge. Akan tetapi menurut pemaparan salah satu orang Aboge, Cak Mundir, istilah ini merujuk pada semua orang dengan tingkat spiritualitas tertentu. Dalam perspective orang awam, orang-orang yang demikian tersebut sering diasumsikan sebagai orang ngerti, orang bijak dan bahkan juga orang sakti. Karena, orang-orang tersebut memiliki tingkatan spiritualitas yang lebih tinggi dari pada orang awam pada umumnya.

Dalam perspective Cak Mundir ada dua macam orang yang digolongkan dalam kata Aboge. Yang pertama adalah orang Aboge yang berkonsentrasi hanya pada spiritualitas personal seperti yang dilakukan oleh Cak Mundir dan teman-temannya yang ada di desa Jabon Tegal. Spiritualitas personal di sini maksudnya adalah pemahaman yang mengacu pada spiritualitas. Dan yang kedua adalah orang Aboge yang bukan hanya mengacu pada spiritualitas tetapi juga ritual-ritual kejawen seperti ritual wayangan, nyekar (ziarah makam) dan juga yang lainnya seperti yang ada di desa Kembang Ringgit dan juga desa Pulorejo. 
Jika menganalisa pemaparan tersebut, meskipun dua macam golongan tersebut termasuk dalam kejawen akan tetapi terdapat sedikit perbedaan. Perbedaannya terkait dengan orang yang melakukan praktek kejawen seperti yang dicontohkan di atas dan yang tidak melakukan praktek kejawen tersebut tetapi hanya menjalankan ajaran kejawennya atau dalam artian peningkatan spiritualitas tanpa melakukan praktek-praktek kejawen semacam hal-hal di atas.

Jika demikian pendapat lain juga dikemukakan oleh Mas Jaka, seorang yang juga bias dikategorikan Aboge dalam perspective Cak Mundir. Meskipun Mas Jaka tidak mempunyai pemahaman yang sama sepertihalnya pemaknaan Aboge dalam perspective Cak Mundir, akan tetapi dia mempunyai perspective sendiri terkait kriteria Aboge menurut pemahamannya. Aboge dalam perspective Mas Jaka adalah orang-orang yang sakti yang mempunyai tingkat spiritualitas yang tinggi, orang-orang yang memiliki kekuatan berkenaan dengan pengetahuannya tentang ketuhanan dan juga orang-orang yang berhasil menemukan jati dirinya sebagai manusia.

Sedangkan dalam pandangan Mbah Khusein, orang Aboge adalah orang yang sudah mengetahui dirinya sendiri dan mau belajar untuk mencari jati dirinya sendiri, dalam artian orang tersebut sudah memiliki sedikit pengetahuan tentang ketuhanan. Kebanyakan orang yang semacam itu hanya bias diketahui atau dilihat oleh orang yang mempunyai pemahaman yang sama. Ringkasnya keberadaan, apakah itu termasuk dalam kategori orang Aboge atau bukan, bias diketahui oleh orang Aboge yang lain dan orang yang tidak memiliki tingkat spiritualitas tertentu tidak bias melihatnya.

Cak Andhim, salah seorang yang bias dikategorikan sebagai Aboge, menurut Cak Mundir, karena dia mempunyai pemahaman dan tingkat spiritualtas tinggi, juga menyatakan hal yang sama bahwasanya orang Aboge itu adalah orang dengan tingkat keimanan dan kepasrahan tinggi kepada sang pencipta. Selain itu, orang-orang seperti itu biasanya tahu segala sesuatu yang tidak diketahui oleh orang lain. Sama sepertihalnya orang yang memiliki karomah semacam kyai-kyai sepuh yang ada di pondok-pondok salafi dan juga penganut ajaran torekat. Alasannya, karena sebagian dari mereka sudah mempelajari ilmu hakekat dan mengimplementasikannya dalam kehidupan sehari-hari.

Menurut Cak Mundir ada 4 tingkat dalam pandangan orang Jawa mengenai tingkat spiritualitas. Pada tahapan awal yaitu dimana orang mengetahui tentang apa dan siapa yang dipujanya maka tahapan awal tersebut dinamakan tingkatan Aboge. Kemudian setelah orang itu melewati tahapan Aboge maka orang tersebut akan naik ketahapan selanjutnya yang disebut 
tingkatan laduni. Laduni jika diartikan secara gambling adalah tahapan dimana orang mengetahui segala sesuatu tanpa mempelajarinya terlebih dahulu. Setelah melewati tahapan laduni maka tingkatan selanjutnya adalah tingkatan langsung. Langsung merupakan sebuah tingkatan dimana orang yang mencapai tingkatan tersebut diberikan pengetahuan yang luas. Dan yang terakhir adalah tingkatan tembus. Tingkatan ini adalah tingkatan spiritualitas tertinggi dalam pandangan orang Jawa. Pada tingkat ini manusia bias dikatakan sudah menyatu dengan dzat ketuhanannya.

Istilah lain untuk penyebutan tingkatan tertinggi ini, menurut Mas Jaka adalah tercapainya rasa sejati. Sejatinya rasa dimana orang yang mencapai tingkat ini bias benar-benar merasakan kehadiran sang penciptanya atau tuhan. Tetapi untuk mencapai tingkat ini menurut maz zaka dibutuhkan waktu yang tidak sebentar dan juga tidak sembarangan orang mampu pada tahapan ini. Untuk mecapai tingkat ini pada mulanya orang harus mengerti dahulu tentang ilmu sejati. Ilmu sejati dalam pandangan Mas Jaka adalah segala jenis pengetahuan tentang ketuhanan, dunia dan kemanusian. Setelah ilmu sejati dipahami barulah tingkat selanjutnya yaitu rasa sejati. Karena ketika seseorang mendapatkan ilmu sejati orang tersebut belumlah tentu mendapatkan atau mengerti tentang rasa sejati akan tetapi ketika orang sudah mengerti rasa sejati maka orang tersebut secara tidak langsung mendapatkan ilmu sejati juga.

Dalam pandangan Mbah Khusein, yang perlu dilakukan untuk mencapai tingkat ini adalah pandai-pandai mempelajari tentang rasa. Karena rasa adalah segalanya. Segala sesuatu ditentukan oleh rasa itu sendiri yang mana ketika orang itu sudah mencapai tingkat pemahaman atau pengertian tentang rasa, maka semua hal terasa lebih indah dan menyenangkan. Dan itulah tingkat tertinggi dari ajaran kejawen yaitu pemahaman tentang rasa, "Roso sejati, sejatine roso" (rasa sejati dan sejatinya rasa).

Jika melihat dari sedikit pemaparan di atas, perspective-perspective yang dikemukakan oleh empat orang di atas dalam kaitannya terkait definisi Aboge bahwasanya kata Aboge itu merupakan sebuah kata yang merujuk pada sebuah tingkatan spiritualitas individu yang lebih tinggi dari individu-individu lainnya (orang awam). Karena pada dasarnya, ketika orang sudah mencapai tingkatan Aboge maka orang tersebut cenderung berprilaku pasrah dengan kehidupan yang diberikan oleh tuhan dan menerima segala ketentuan-ketentuan yang sudah ditetapkan oleh tuhan. menjalankan kehidupan apa adanya tanpa menginginkan sesuatu yang sifatnya duniawi. Karena hal-hal tersebut sudah menjadi ajaran yang diterima oleh mereka. 
Terkait dengan ajaran orang Aboge, sebenarnya ajaran Aboge ini bias dikatakan sama halnya dengan ajaran Kejawen karena lebih merujuk kepada ajaran tentang kemanusiaan dalam artian bagaimana manusia itu sendiri memahami dirinya sendiri karena semua yang ada di alam itu intinya kepada manusia itu sendiri. Meskipun tanpa menghilangkan eksistensi ketuhanan dalam ajarannya, namun muaranya tetap pada manusia itu sendiri.

Cak Mundir pernah berkata ada 4 kewajiban manusia. 4 kewajiban manusia itu adalah kewajiban manusia kepada dirinya sendiri, kewajiban manusia kepada Tuhan, kewajiban manusia kepada alam dan yang terakhir kewajiban manusia kepada manusia yang lainnya. Untuk kewajiban yang pertama dimaksudkan adalah untuk menjaga diri sendiri, dalam artian manusia tidak boleh terlalu memaksa dan juga terlalu membiarkan dirinya sendiri. Seperti contohnya pada saat perut kita lapar, karena kita tahu bahwasanya perut adalah bagia tubuh kita, maka ketika kita lapar kita perlu makan untuk menjaga tubuh kita agar tetap fit. Akan tetapi ketika kita lapar dan kemudian kita membiarkan saja, maka yang akan terjadi adalah kita akan sakit. Hal tersebut merupakan contoh singkat dari kewajiban yang pertama.

Kewajiban yang kedua adalah kepada tuhan. Kewajiban kepada tuhan maksudnya adalah sebagai ciptaannya, manusia tidak seharusnya melupakan tentang penciptanya, untuk itu tugas manusia adalah menyembah sang pencipta dengan melakukan apa yang baik menurut perintahnya dan meninggalkan yang buruk.

Kewajiban yang ketiga adalah kewajiban kepada alam artinya manusia diciptakan di bumi dan bumi sudah menjadi sumber kehidupan manusia itu sendiri. Untuk itu sudah kewajiban manusia untuk menjaga alam sekitarnya dan tidak merusak alam sekitar karena alam dalam pandangan orang Aboge itu adalah makhluk karena ketika alam dirusak, hal tersebut juga akan berdampak kepada manusia itu sendiri.

Dan yang terakhir adalah kewajiban kepada sesame manusia artinya manusia tidak dilahirkan sendiri akan tetapi berkelompok, bersosial dan untuk itu perlunya individu saling menghormati, menolong dan berinteraksi dengan manusia lainnya. Contohnya bekerja dan juga berkeluarga.

Dari hal-hal tersebut Jika dipahami perkataan Cak Mundhir terkait dengan 4 kewajiban manusia, pada intinya semua kembali kepada manusia itu sendiri. Bagaimana manusia itu menempatkan dirinya sendiri di alam dengan baik dan benar. 
Masih terkait dengan hal tersebut, dalam ajaran kejawen terdapat istilah "Dulur Papat Kalimo Pancer" yang artinya adalah manusia itu sendiri. Istilah tersebut seringkali digunakan untuk memahami jati diri manusia itu sendiri. Meskipun begitu, sebagian orang Jawa mempunyai pandangan dan pendapat masing-masing mengenai istilah tersebut. Seperti pemaparan yang diberikan Mbah Khusein.

Sedulur Papat Kalimo Pancer itu adalah makna diri manusia itu sendiri. Pengertian papat (empat) di sini adalah manusia terdiri dari empat bagian yang pertama adalah Raga, Sukma, Roh, dan Nyawa. Sedangkan yang kalimo (kelima) adalah manusia itu sendiri sebagai wadahnya. Raga adalah tubuh dari manusia itu sendiri yang berasal dari intisarinya bumi, sukma dari intisari air, roh dari intisari sinar matahari, dan nyawa dari intisarinya angin. Empat hal tersebut merupakan satu kesatuan dari manusia itu sendiri akan tetapi berbeda dalam tugasnya. Tugas disini diartikan sebagai pembawa atau pengantar dari manusia itu sendiri dan juga bias diartikan sebagai penjaga dari manusia itu sendiri. Jika manusia mengerti akan sejatinya manusia itu sendiri maka secara tidak langsung dia akan memiliki pengetahuan tentang rasa sejati. Rasa sejati adalah rasanya diri sendiri, bukan rasanya makanan, perempuan cantik, mobil bagus, rumah mewah atau yang lain, dan tempatnya berada di pernafasan dan detak jantung. Dengan rasa itu manusia bias merasakan dan mengetahui siapa yang disebut tuhan.

Sedangkan Mas Jaka memandang dulur papat kalimo pancer adalah suatu entitas yang berbeda dari manusia itu sendiri tapi mempunyai wujud yang sama dengan manusia secara jasmaniyah. Yang dimaksudkan dengan entitas yang berbeda disini adalah hal tersebut tidak bias dilihat dengan kasat mata, hal tersebut hanya bias datang kalau seandainya manusia itu sendiri sudah mengenal sejati dirinya sendiri. Meskipun begitu setiap manusia dalam pandangan Mas Jaka mempunyai dulur papat kalimo pancar dalam artian manusia membawa hal tersebut setiap waktu dan juga manusia terikat dengan hal tersebut, akan tetapi kebanyakan manusia tidak mengetahui akan keberadaan dulur papat kalimo pancer sehingga mereka tidak bias mengetahui sejati dirinya sendiri. Berbeda dengan orang yang sudah bias mngetahui atau bertemu dengan dulur papatnya, ketika orang atau manusia tersebut sudah bias bertemu dengan dulurnya, maka orang tersebut akan menerima pengetahuan sejati atau ilmu sejati terkait dengan jati diri manusia.

Selain itu, dalam pemahaman Cak Mundir sedulur papat kelimo pancer adalah sifat dari manusia itu sendiri. Yang pertama adalah sifat Mutmainah, sifat yang bersemayam dijantung 
berwujud air berwarna putih, dengan watak yang suci dan sungguh-sungguh, pintunya ada di hidung. Hidung adalah alat atau panca indra yang tak pernah bohong. Yang kedua adalah Amarah yang bersemayam di empedu, berwarna merah dan berwatak keras, angkara murka dan pintunya ada di telinga. Manusia bisa merasakan baik dan buruk karena mempunyai telinga dan ketika mempunyai keinginan yang jahat atau yang baik maka itu karena darah yang berwarna merah. Yang ketiga adalah Supiyah, yang bersemayam dilobang tali pusar, berwujud angin yang berwarna kuning, berwatak mengumbar hawa nafsu, pintunya berada di mata. dalam istilah kejawen mata diartikan sebagai "lanange jagad" (yang paling berkuasa). mata bisa digunakan untuk melihat semua hal yang wujud. Yang keempat adalah Aluamah, yang bersemayam dilambung yaitu tempat penyimpanan makanan, dilambangkan dengan wujud tanah yang berwarna hitam, mempunyai kesenangan untuk merasakan makanan yang enak-enak, pintunya ada di mulut. Dan yang kelima juga yang terakhir adalah hidup yaitu dimaksudkan untuk menghidupi empat perkara yang di atas dan hidup adalan pusatnya yang menghidupi empat hal tersebut.

Mbah Khusein mengartikan bahwa hidup adalah sebuah titipan, manusia itu sanggup untuk menghidupi hidupnya dan apa yang sudah dititipkan harus dijaga, namun sayangnya pada zaman sekarang manusia itu sering lupa akan sejatinya hidup jadi yang dihidupi dan dipellihara cuman raganya saja dan tidak mau menjaga hidupnya. Sepertihalnya raga kalau tidak diberi makan komplain. Padahal, semua itu sudah ada yang mengatur, masalah makan dan tidak makan, rejeki semuanya sudah ada yang mengatur yaitu dzat pemberi kehidupan itu sendiri. Pada saat ini, manusia hanya terfokus pada kesenangan duniawi, meskipun itu bener tapi cuman kurang bener. Dalam artian manusia diberi hawa nafsu dan hawa nafsu adalah pemberian dari sang pencipta, jika terlalu focus pada hawa nafsu maka sejatinya diri akan tertutupi dan manusia akan tidak bias melihat bagaimana sejatinya manusia itu sendiri karena sudah terlalu terbutakan oleh hawa nafsu. Padahal rasa senang dari hawa nafasu tersebut tidak dapat di cari, keenakan juga tidak dapat dicari, tapi ketika manusia sudah bisa merasakan yang sejati maka kesenangan dan keenakan juga akan ikut dengan sendiri di dalamnya. Oleh karena itu, hanya dengan memperoleh rasa yang sejati semuanya bias mendapatkan kesenangan dan keenakan sejati. Dan hal tersebut bias di dapatkan atau dirasakan melalui keluar masuknya nafas dan berdetaknya jantung. Dalam pandangan Mbah Khusein ajaran tersebut merupakan ajaran kejawen yang asli. 
Sama seperti yang diungkapkan oleh Mas Jaka terkait dengan ajaran kejawen. Menurut pemaparannya tujuan atau inti dari ajaran kejawen adalah rasa sejati. Rasa dari segala rasa, rasa yang memungkinkan manusia menjadi sangat dekat dan merasakan kehadiran sang penciptanya. Dan orang yang mempelajari ajaran kejawen tersebut biasanyanya besikap ikhlas, sabar, tawakal, lilo dan nerimo. Mas Jaka juga mengungkapkan bahwa ajaran kejawen adalah ajaran tentang hakikat, ajaran yang lebih mengedepankan kepada pendekatan diri kepada tuhan yang maha esa, dalam islam lebih dikenal dengan sebutan ilmu tauhid.

Cak Andhim yang juga seorang dengan tingkat spiritualitas tinggi juga mengatakan bahwasanya ajaran kejawen lebih tua dari pada ajaran islam dan ajaran kejawen juga mempunyai banyak kesamaan dengan ajaran islam dalam hal-hal tertentu. Seperti contohnya pemahaman terhadap tuhan yang maha esa, dalam ajaran kejawen dan islam tuhan hanya ada satu. Meskipun dalam penamaan atau penyebutan terkait siapa atau dimana tuhan berbeda, akan tetapi pada hakikatnya tuhan yang dimaksud adalah sama. Dalam ajaran kejawen tuhan bias dinamakan atau disebut apa saja tergantung dari individu masing-masing. Selain itu, ajaran kejawen tidak mengenal yang namanya dewa-dewa seperti yang ada di dalam agama hindu. Dan juga ajaran kejawen menurut Cak Andhim adalah ajaran tentang manusia dan alam, karena manusia adalah bagian dari alam dan alam adalah bagian dari manusia.

Salah satu ilmu yang unik dalam menjelaskan semua ajaran yang berhubungan antara ajaran kejawen atau ajaran islam adalah ilmu "Gatol Loco". Ilmu Gatol Loco juga termasuk ajaran kejawen. Seperti yang di utarakan oleh Cak Andhim bahwasanya ilmu gatol loco adalah ilmu kejawen yang sudah tua. Ajaran gatol loco ini adalah ajaran mengait-ngaitkan dalam bahasa Jawa disebut “Gato'-Gato' No". Mengaitkan-ngaitkan di sini maksudnya adalah merasionalisasikan maksud ajaran yang sudah ada dalam ajaran kejawen ataupun islam yang sifatnya sulit untuk dimengerti. Kalau dalam islam mungkin setara dengan yang disebut ilmu tafsir. Merasionalisasikan artinya menjelaskan maksud yang terkandung dalam ajaran tersebut dengan bahasa yang mudah dimengerti. Pasalnya, ajaran kejawen bagi orang yang tidak mempunyai pemahaman yang cukup luas atau pengetahuan yang cukup tinggi akan sangat sulit untuk dimengerti dan kemungkinan akan mengakibatkan kebingungan dan salah arah.

Misalnya, tentang puasa, apa itu puasa dan kenapa dengan puasa?. Untuk memahami makna puasa dikaitkan dengan ilmu Gato Loco maka akan sepertihalnya demikian. Puasa dalam bahasa Jawa disebut "Poso". Puasa dalam pemahaman sehari-hari diartikan kondisi untuk 
menahan hawa nafsu (makan dan minum), sedangkan penafsiran menggunakan ajaran Gatol Loco, poso adalah "Ngeposno Roso" (memberhentikan rasa) bukan hanya merujuk pada permasalahan makan dan minum tetapi juga segala macam rasa yang dimiliki manusia, rasa ingin melihat, mendengar, berbicara, tidur dan juga lain-lainnya. Selain itu, kenapa dengan puasa, karena ketika manusia melakukan puasa entah menahan makan atau minum, maka seluruh aktifitas akan melemah dan ketika melemah tubuh atau yang lain akan menjadi malas melakukan apapun dan ketika tidak melakukan apapun secara tidak sadar manusia akan terhindar dari perbuatan memfitnah orang, berbuat jahat terhadap orang lain, dan lain sebagainya. Hal tersebut yang dinamakan sebagai ilmu gatol loco.

Pada dasarnya jika mencermati secara seksama bagaimana pengertian dan definisi orang Aboge berserta ajarannya, dapat dikatakan bahwasanya ajaran Aboge adalah ajaran kejawen itu sendiri secara hakikatnya. Mengapa demikian, karena inti dari Aboge dan kejawen itu merujuk pada satu titik yang sama yaitu merujuk pada ilmu hakikat. Selain itu, yang menjadi perbedaan dari Aboge dan kejawen adalah spesifik ajarannya. Sepertihalnya penjelasan-penjelasan di atas, dari beberapa orang, mereka mempunyai pemahaman yang berbeda-beda mengenai istilah sedulur papat kelimo pancer. Akan tetapi secara intinya, semuanya sama saja yaitu kejawen.

\section{RITUAL ABOGE}

Pada umumnya praktek-praktek ritual yang dilakukan orang-orang ini biasa disebut "laku". Laku adalah bahasa Jawa yang mempunyai arti melakukan atau mengerjakan sesuatu menurut apa yang diperintahkan dan menurut ajaran orang Jawa. Praktek ritual dalam pandangan Aboge bukanlah suatu praktek yang harus dilakukan secara komunal tetapi juga bias dilakukan secara personal. Dalam artian ritual yang dilakukan tidak semua orang Aboge melakukan hal yang sama dengan Aboge yang lainnya akan tetapi seperti yang saya sebutkan di atas, ada juga ritual yang dilakukan secara bersamaan. Ritual yang dilakukan secara bersamaan ini biasanya merujuk pada Aboge yang sudah ada kelompoknya seperti halnya aliran kejawen rasa sejati. Aliran kejawen rasa sejati juga dikategorikan sebagai Aboge karena mereka mempunyai pemahaman dan tingkat spiritualitas yang intinya sama seperti tingkatan Aboge di atas. Oleh karena itu, pemahaman mengenai praktek ritual Aboge bias dikategorikan menjadi dua yaitu yang secara personal dalam artian dilaksanakan oleh individu masing-masing dengan bentuk dan 
pola tertentu dan yang secara komunal seperti praktek ritual yang dilakukan oleh aliran kejawen rasa sejati.

Praktek laku bagi orang Aboge yang individual tidak bias dijelaskan secara general seperti apa prosesnya, karena mereka pada umumnya, menjalankan praktek laku berdasarkan pesan yang diterima, sedangkan pesan yang diperoleh menurut Cak Mundhir sifatnya personal atau sendiri-sendiri dan tiap orang itu menerima pesan yang berbeda-beda sekaligus berbeda pula perintah lakunya. Selain itu, tidak ada ketetapan waktu kapan dan dimana praktek laku tersebut dilakukan. Sedangkan, praktek laku bagi orang Aboge yang ada dalam sebuah kelompok menurut pemaparan dari Mas Jaka, mereka cenderung melakukan praktek laku berdasarkan apa yang diperintahkan oleh sesepuh aliran tersebut. Dalam hal ini, praktek laku yang dikerjakan biasanya lebih bersifat komunal dalam artian terkadang mereka melakukannya secara bersama dan kadang juga sendiri-sendiri tergantung perintah dari sesepuhnya dan juga kemampuannya. Meskipun terdapat pemahaman yang berbeda terkait praktek laku yang dilakukan oleh dua jenis orang Aboge (personal dan komunal), akan tetapi, praktek laku yang dijalankan mempunyai tujuan yang sama yaitu pencarian jati diri manusia. Meskipun demikian tidak menutup kemungkinan ada juga laku ritual yang dimaksudkan untuk mencari kesaktian.

Bagi Aboge individual petunjuk yang mereka terima bias melalui mimpi dan juga bisikan-bisikan. Sedangkan bagi yang komunal mereka menerima petunjuk dari sesepuh aliran mereka. Dalam hal ini, para pelaku praktek laku tersebut melakukan suatu perjalanan tanpa menggunakan alat transportasi apapun alias berjalan kaki ke suatu tempat yang tidaklah dekat dan praktek laku ini biasanya dilakukan oleh orang Aboge yang individual maupun komunal.

Untuk itu berikut ini beberapa istilah untuk praktek laku yang dilakukan oleh orang Aboge personal atau komunal.

\section{- MBEGENDENG (Berprilaku Gila)}

Mbegendeng secara harfiah diambil dari kata "gendeng" artinya gila. Mbegendeng seacara istilah merupakan sebuah sikap atau prilaku yang menyerupakan orang gila dari tindakan sehingga orang yang melihatnya menganggap orang tersebut gila. ${ }^{3}$ dalam artian kasarannya sama dengan laku gila. Laku gila biasanya dilakukan kapan saja dan dimana saja. Praktek laku

\footnotetext{
${ }^{3}$ Pengertian tersebut berasal dari pemahaman penulis saat wawancara dengan informan.
} 
mbegendeng ini biasanya dilakukan oleh orang Aboge yang individual bukan komunal. Mereka yang melakukan ritual ini biasanya melakukan atau memakai pakaian yang aneh-aneh yang mungkin hamper mirip dengan orang gila. Oleh karena itu, banyak orang yang memandang mereka gila karena praktek laku yang mereka lakukan sama dengan orang gila. Jadi istilah tersebut dipakai untuk menamakan laku orang tersebut. Seperti contohnya menurut pengakuan salah seorang Aboge, orang tersebut berjalan kaki mengelilingi kampongnya dengan hanya memakai celana dalam (CD) sambil menyeret tali yang disitu terikat beberapa kaleng bekas kaleng susu sehingga ketika dia berjalan kaleng-kaleng tersebut menimbulkan suara gaduh yang tidak enak didengar. Ada juga laku mbegendeng yang berupa pergi ke tengah sawah pada malam hari dan melihat ke arah langit, mulai dari jam 10 malam sampai dengan jam 5 pagi. Dan juga laku mbegendeng lainnya seperti berjalan ke tengah sawah tanpa mengenakan pakaian sebelum matahari terbit dan setelah itu menatap matahari mulai dari terbit sampai terbenamnya matahari.

Laku mbegendeng ini menurut pemaparan salah satu orang Aboge adalah sebagai bentuk cara untuk memutuskan hati manusia yang lain, dalam artian, menimbulkan asumsi-asumsi negative terhadap dirinya. Dengan demikian, setelah terputusnya hati manusia yang lain baru setelah itu menuju ke tahapan yang sejati yaitu pendekatan terhadap tuhan. Karena pada dasarnya sifat dari orang gila itu diibaratkan seperti anak kecil mereka melakukan apapun yang mereka mau tanpa ada pertimbangan akal dan hokum. Sedangkan anak kecil dalam pandangan Aboge adalah suci belum tercemar apapun. Dengan demikian laku mbegendeng tersebut dimaksudkan untuk kembali suci dari tindak-tindakan masa lalu yang kurang baik. Secara logika, ketika tindakan-tindakan tersebut berkaitan dengan orang lain maka, ketika orang lain mengetahui bahwa orang yang bersangkutan itu gila, maka mereka akan melupakan semua kesalahankesalahan yang sudah pernah dilakukan.

\section{- Ngembong ()}

Ngembong adalah praktek laku hidup di jalan tanpa membawa sesuatu bekal apapun dan hanya mengandalkan keyakinan bahwa tuhan yang akan memenuhi kebutuhan sehari-hari manusia. Hidup di jalan maksudnya adalah melakukan suatu perjalanan ke suatu tempat tertentu tergantung pada petunjuk yang sudah diterima. Terdapat banyak sekali praktek laku ngembong dalam ajaran kejawen tergantung pada petunjuk yang mereka dapatkan atau perintah yang 
diberikan oleh guru aliran kejawen yang mereka anut. Laku ngembong ini bias dilaksanakan oleh orang Aboge secara personal ataupun komunal.

Sepertihalnya salah satu bentuk laku ngembong yang dipaparkan oleh Pak Budi (salah satu penduduk desa yang punya pengetahuan laku kejawen). Laku ngembong yang diutaraka oleh Pak Budi sifatnya personal bukan komunal. laku ngembong menurut pemaparan beliau adalah laku ngembong "pitung pasaran, pitung pawonan dan pitung babakan” (tujuh pasar, tujuh tempat sampah, dan tujuh kali berendam di sungi). Maksud dari tujuh pasar adalah orang harus berjalan kaki sampai menemukan pasar sebanyak tujuh kali dan ketika sudah di pasar tersebut orang itu harus berada di sana dan bersemedi selama beberapa waktu tergantung hitungan pasar yang sudah ditemukan. Misalnya pada saat menemukan pasar yang pertama, orang itu harus bersemedi selama satu hari, ketika menemukan pasar yang kedua, orang itu bersemedi selama dua dan kemudian sampai seterusnya selama tujuh kali dan tujuh hari. Begitupun juga dengan tujuh pawonan, orang tersebut harus berjalan sampai menemukan tempat pembuangan sampah yang biasanya digunakan oleh orang lain untuk membuang sampah rumah tangga selama tujuh kali dan tujuh hari. Setelah itu tujuh babakan, ritual ini adalah ritual berendam di sungai selama tujuh kali di tujuh tempat yang berbeda yang mana terdapat tempat untuk orang BAB (buang air besar) dan orang yang melakukan laku ngembong tersebut harus berendam disitu, dekat dengan tempat orang BAB. Tujuan untuk laku ngembong yang seperti di atas menurut pemaparan Pak Budi adalah untuk mencari ilmu sejati dan juga mendapatkan kesaktian. Pasalnya menurut pemaparan beliau ketika orang itu sudah berhasil menjalani laku tersebut maka orang itu akan mendapatkan beberapa kesaktian seperti dapat menyembuhkan orang sakit tanpa harus melalui obat-obatan, bias melihat arwah orang mati, jin dan lain-lainnya.

Sedangkan praktek laku ngembong lainnya adalah laku ngembong seperti yang dilakukan oleh Cak Mundhir. Cak Mundir adalah orang Aboge yang melakukan laku secara personal. Beliau melakukan laku ngembong waktu sebelum menikah dan bentuk lakunya berupa jalan kaki mulai dari Mojokerto sampai ke Jakarta tanpa bekal apapun sambil memakai daster (pakaian orang hamil). Laku ngembong ini dalam pandangan Cak Mundir dimaksudkan sebagai belajar karma dan istilah lain untuk laku ngembong ini adalah "lungo kaji" (pergi haji). Istilah lungo kaji ini sebenarnya berasal dari tuntunan langit yang berbunyi "lungo ngeji" (jalan sambil membaca mantra tertentu). Tuntunan langit menurut Cak Mundhir adalah dimana segala petunjuk berasal, pengetahuan tentang ajaran dan praktek laku berasal dari sana. Sedangkan tujuan dari laku ini 
menurut pemaparan beliau selain sebagai bentuk pencarian jati diri dan juga sebagai bentuk penebusan karma. Karma dalam pandangan beliau adalah sebuah konsekuensi dari kata yang diucapkan dalam artian karena ingin mengetahui makna kata yang diucapkan maka beliau harus membayar pengetahuan tentang kata tersebut dengan cara ngembong tersebut.

Beliau manjalankan laku ngembong ini hanya selama beberapa hari dan tidak mencapai waktu selama satu bulan. Menurut ceritanya ketika sudah sampai di Jakarta, beliau disambut dengan orang banci setelah itu beliau mendapatkan bisikan yang menyuruhnya untuk kembali pulang. Orang banci dalam pandangan Cak Mundhir dianggap sebagai orang suci karena orang banci adalah ciptaan tuhan yang special dikarenakan mempunyai dua kepribadian. Di satu sisi dia adalah laki-laki dan di sisi lain dia juga perempuan. Oleh karena itu, beliau memaparkan bahwa do'a dari orang banci lebih mudah terkabul dari pada do'a dari sepuluh kyai sekalipun.

Selain itu, laku ngembong yang sifatnya personal lainnya adalah laku ngembong yang dilakukan oleh Mbah Khusein. Meskipun sulit untuk didiskripsikan akan tetapi laku yang dilakukan oleh Mbah Khusein termasuk juga laku ngembong. Pasalnya Mbah Khusein melakukan laku dari dulu sampai sekarang dan beliau tidak tinggal di dalam sebuah masyarakat atau lingkungan social tertentu melainkan hidup di gua. Mbah Khusein adalah orang Aboge yang sudah berumur 77 tahun. Dia mulai melakukan laku sebelum umur 50 an. Menurut kisahnya dia mulai melakukan praktek laku pada saat dia mendapatkan bisikan dari nenek moyangnya atau dalam ajaran Jawa disebut "dulurnya" (saudaranya). Setelah itu, dia menjalankan laku tersebut. Bisikan yang didapatnya adalah untuk segera membeli sebuah gua yang tidak jauh dari rumahnya dan tentu saja gua yang mau dibeli tidak dibeli dari manusia melainkan dari makhluk selain manusia. Gua tersebut sekarang yang disebut sebagai gua putih karena tembok yang berupa bebatuan berwarna putih. Membeli disini tidak merujuk pada jual beli pada umumnya manusia akan tetapi membeli dengan membayar berupa memahami lima panca indra. Lima panca indra tersebut adalah "pandulu, pangrungu, pangambu, pangucap lan pangroso", (pemelihat, pendengaran, penciuman, pengucapan, dan perasaan). Dengan memahami itu semua baru gua yang disuruh membeli akhirnya bias ditempati. Untuk memahami lima hal tersebut menurut Mbah Khusein memerlukan waktu yang tidak sebentar. Beliau memahamai lima hal tersebut selama lebih dari dua tahun lamanya. Setelah memahami lima hal tersebut pada umur 60 tahun mulailah beliau menempati gua tersebut sampai saat ini. Menurut pemaparan beliau, gua 
yang beliau tempati adalah gua tempat penyucian diri, selain itu bias juga digunakan untuk ketenangan atau kedamaian jiwa.

Sedangkan tujuan beliau untuk tinggal di sana adalah selain untuk mengemban amanah yang diberikan kepada beliau oleh spiritual being yang menyuruhnya, juga untuk belajar menemukan jati dirinya. Setelah itu, beliau tinggal di dalam gua semenjak itu. Gua tersebut juga tidak ada yang mengetahui sama sekali kecuali Mbah Khusein sendiri. Dan setelah 7 tahun berada dalam gua tersebut, barulah ada orang lain yang datang kesana. Banyak sudah orang yang berkunjung ke gua tersebut, bukan hanya dari kalangan orang kejawen sendiri seperti dukun, pendeta, biksu dan militer tetapi juga pejabat-pejabat kabupaten. Mereka kesana dengan tujuan bermacam-macam, ada yang mencari kedamaian, ada yang mencari ilmu, ada yang ingin bertapa dan juga ada yang latihan.

Demikian laku ngembong yang sifatnya personal menurut pandangan orang Aboge. Sedangkan laku ngembong yang sifatnya kolektif biasanya dilakukan oleh orang-orang Aboge yang sudah terorganisir. Dalam artian mereka mempunyai tempat untuk berkumpul dan waktu yang ditentukan untuk melaksanakan perkumpulan serta ritual-ritual yang lain. Hal tersebut, seperti laku ngembong yang dilakukan Mas Jaka dan temen-temennya.

Mas Jaka adalah seorang Aboge yang mengikutin ajaran aliran kejawen yang bernama roso sejati seperti yang sudah dijelaskan sebelumnya. Aliran roso sejati yang diikuti Mas Jaka merupakan suatu aliran kejawen yang sudah terorganisir dan resmi karena aliran tersebut sudah mendapatkan ijin dari pusat aliran kejawen yang ada di keratin solo. Bahkan aliran tersebut sudah diakui di keraton solo dengan bukti sebuah bintang sebagai pengesahannya. Tidak hanya itu, para anggota pengikut aliran tersebut bahkan mempunyai kartu anggota aliran kejawen sebagai buktinya. Hal tersebut menjadi sangat penting karena menurut pemaparan Mas Jaka ketika suatu aliran yang berbau kejawen muncul, mereka harus mendaftarkan diri ke keratin solo untuk mendapatkan surat pengesahan di sana. Dan jika aliran tersebut tidak mendaftarkan secara resmi, maka aliran tersebut akan dianggap sesat dan bahkan akan dipaksa bubar oleh pengurus aliran kejawen di keratin solo. Selain itu, Mas Jaka juga memaparkan bahwa ada tim investigasi khusus untuk meninjau perkembangan aliran-aliran kejawen tersebut. Hal tersebut pernah terbuktikan ketika Mas Jaka bertemu langsung dengan tim investigator aliran kejawen pada saat berkumpul di padepokannya. Pada waktu itu, tim investigator tersebut berjumlah dua orang, satu 
perempuan dan satu laki-laki. Tim investigator tersebut bahkan menunjukkan kartu identitas mereka sebagai bukti resmi dari keratin solo. Dengan demikian, hal tersebut menunjukkan bahwa aliran-aliran kejawen yang ada di Jawa sudah sangat terorganisir dengan baik dan sebagai buktinya adalah didirikannya pusat untuk mengorganisir aliran-aliran tersebut di keratin solo

Laku ngembong yang dilakukan Mas Jaka yaitu berupa jalan kaki dari padepokan tempat dia menimbang ilmu di Mojokerto sampai ke puncak gunung arjuna di malang. Setelah sampai di puncak gunung arjuna hal yang dilakukan adalah menancapkan bendera merah putih yang dibawa dari padepokan di atas puncak gunung arjuna. Gunung arjuna dalam pandangan Mas Jaka adalah pusat berkumpulnya aliran-aliran kejawen yang ada di Jawa timur. Waktu pelaksanaanya untuk laku ngembong tersebut adalah pada waktu bulan selo setelah tanggal 9. Bulan selo adalah bulan setelah bulan syawal dan sebelum melakukan laku tersebut dilakukan perkumpulan sebagai persiapannya. Diantara persiapannya adalah diadakannya ritual semacam ritual selamatan berupa istighosah, setelah itu mocopat dan makan-makan, yang dilaksanakan pada pukul 10 malam sampai selesai. Kemudian pada pukul 1 pagi, acara selanjutnya adalah mandi di Sumber Jati (salah satu sumber pemandian yang ada di kota Mojokerto), setelah selesai mandi, pada pukul 3 pagi baru berangkat laku ngembong. Sebelum berangkat, para anggota aliran diberi bekal seadanya dan dikasih suatu amalan. Amalan di sini berupa suatu saran dan doa contohnya pada proses laku ngembong para anggota disuruh mengambil daun sedapat-dapatnya di hutan, digigit dan kemudian doa yang dikasih diwirid sampai tiba dipuncak gunung.

Cak Andhim yang juga seorang Aboge pernah menceritakan bahwa teman-temannya yang mengikuti aliran kejawen juga sering melakukan laku ngembong ke gunung-gunung di Mojokerto seperti gunung welirang dan penanggungan. Beliau mengungkapkan bahwa laku tersebut sepertihalnya suatu keharusan untuk dilakukan. Bahkan menurut pelaku laku tersebut memaparkan bahwa "wong jowo nek gak muncak berarti jowone gak diakui" (orang Jawa yang tidak pergi laku ke gunung berarti kejawenannya masih diragukan).

\section{- Poso atau Ngeposno Roso (Menempatkan Rasa)}

Poso atau yang disebut puasa dalam bahasa indonesia juga termasuk dalam praktek laku orang Aboge. Akan tetapi, poso dalam pengertian orang Aboge sedikit berbeda dengan puasa yang selama ini diartikan oleh orang awam pada umumnya khususnya orang islam. Meskipun artinya puasa merujuk pada pengertian menahan hawa nafsu akan tetapi maksud dari laku poso 
agak sedikit berbeda dengan praktek puasa yang dilakukan oleh orang awam. Dalam pandangan orang awam khususnya orang islam praktek puasa dimaksudkan menahan rasa lapar dan minum, sedangkan laku poso yang dimaksud dalam orang Aboge adalah bukan hanya menahan nafsu makan dan minum tetapi juga semua hal yang berhubungan dengan rasa. Pada hakikatnya poso bagi orang Aboge diartikan sebagai "ngeposno roso" atau menempatkan rasa. Sama seperti yang penjelasan sebelum-sebelumnya.

Laku poso termasuk juga dalam laku orang Aboge yang dilakukan secara personal. Mas Jaka mengatakan bahwasanya para pelaku laku poso melakukan praktek poso berbeda-beda tergantung pada apa yang diinginkan. Tujuan dari laku poso sendiri juga berbeda-beda menurut pemaparan dari Cak Mundhir puasa itu bertujuan untuk menahan hawa nafsu manusia atas keinginan-keinginannya. Dengan demikian manusia bias meresakan secara langsung bagaimana arti sebuah rasa sejati bukan hanya rasa yang sifatnya fana tetapi juga rasa yang benar-benar sejati. Akan tetapi sifat dari laku poso sendiri berbeda-beda, seprtihalnya apa yang dialami oleh Cak Mundhir pada waktu selesai melakukan laku poso. Alasan dia melakukan laku poso adalah karena dia disuruh oleh pemberi petunjuknya untuk melakukan laku poso sebagai upaya untuk menebus kesalahan yang dilakukannya.

Selain itu, praktek laku poso juga terkadang dimaksudkan untuk menambah kesaktian dalam arti para pelaku praktek poso melakukan poso tersebut supaya ilmunya bertambah. Di samping itu Mas Jaka menambahkan bahwa sanya laku poso juga dimaksudkan sebagai mahar untuk amalan-amalan yang didapat dari gurunya. Dalam artian amalan-amalan yang diberikan oleh gurunya akan berkhasiat ketika si murid mengawalinya dengan melakukan laku poso tersebut.

Meskipun begitu laku poso dalam istilah kejawen sangat bermacam-macam ada laku poso pati geni, poso mutih, poso ngebleng dan juga poso amalan. Poso pati geni dalam pandangan orang Aboge adalah poso yang tidak memakan apapun yang sifatnya bernyawa. Meskipun demikian ada pendapat lain mengenai pengertian laku poso pati geni, menurut sebagian orang kejawen laku poso geni merupakan puasa yang dilakukan selama satu hari penuh 1x24 jam dan dilakukan tanpa boleh terkena cahaya apapun. Poso motih adalah puasa yang pada waktu sahur dan buka hanya memakan nasi putih sekepal dan minum segelas air putih. Poso ngebleng yaitu puasa untuk tidak tidur. Dan Poso amalan yaitu puasa dengan terus mewiridkan 
amalan atau do'a yang sudah diberikan pada waktu tertentu. Selain itu, untuk waktu dalam laku poso itu sendiri bermacam-macam, ada yang tiga hari, tujuh hari, dua puluh satu hari, empat puluh hari, bahkan seumur hidupnya kecuali pada hari-hari tertentu saja mereka tidak berpuasa. Laku poso juga biasanya dilakukan untuk memperingati hari lahir sang pelaku dalam artian hari pasaran lahirnya orang tersebut dalam istilah Jawa disebut Laku Poso Weton.

Laku poso weton dalam pandangan Mas Jaka mempunyai aturan sendiri, laku poso weton dimulai pada jam 12 malam setelah mandi kemudian makan dan minum untuk sahurnya setelah itu tidak boleh tidur dan juga makan atau minum. Dalam proses tidak tidur biasanya disrtai dengan sembahyang atau neng ning dengan aturan menyiapkan kembang telon, the, air putih, kopi dan disertai dupa. Untuk penempatan dari hal-hal tersebut air putih diletakkan sebelah timur karena sebagai lambing munculnya matahari dan juga warna putih, arah selatan itu kembang telon dan dilambangkan dengan warna kuning, arah barat itu teh dan dilambangkan dengan warna merah, dan yang terakhir adalah utara dan dilambangkan dengan warna gelap. Hal-hal tersebut dimaksudkan sebagai upaya untuk merapatkan dulur papat kelimo pancer, kakang kawah adi ari-ari.

Menurut pemaparan Mas Jaka, setelah berhasil menjalankan laku poso weton selama tujuh kali dan tujuh kamis kemudian diadakan bancaan (ritual selametan) dengan menyertakan ayam cemani sebagai sesajinya. Keberhasilan dari sang pelaku praktek poso weton tersebut ditandai dengan bertemunya sang pelaku dengan dulurnya sendiri yang sangat mirip dengan diri kita sendiri.

\section{- Sembahyang}

Sembanhyang dalam istilah orang Aboge diartikan sebagai "Sesembahan Sang Hyang" (menyembah yang agung atau tuhan). Praktek laku ini adalah praktek laku yang kebanyakan dilakukan oleh orang Aboge dalam ritunitas keseharian. Sifat dari praktek laku ini adalah personal dalam artian setiap orang melakukan praktek laku sembahyang secara individu dan tidak harus dilakukan dalam sebuah kelompok. Untuk praktek laku sembahyang sendiri bermacam-macam tergantung orang yang melakukannya. Sedangkan waktu untuk melakukan laku sembahyang tersebut juga bervariasi. Bagi orang Aboge yang communal seperti Mas Jaka, beliau melakukan laku sembahyang pada waktu dini hari setelah jam 12 malam sampai selesai. 
Ritual laku sembahyang dalam pandangan orang Aboge disebut "Neng Ning", Ngeningno Cipto atau mengheningkan cipta. Dalam pengertian lain disebut topo sesaat atau bertapa sesaat, maksudnya yaitu hatinya meninggalkan semua kepentingan dunia. Laku sembahyang dalam pandangan orang Aboge adalah sebagai cara untuk dapat berinteraksi dengan sang hyang atau tuhan. Bentuk ritual dan proses laku sembahyang sendiri menurut penuturan Mas Jaka yaitu beliau duduk bersila sambil mendekapkan kedua tangan di perut sambil menghadap ke timur.

Sedangkan menurut pemaparan Cak Mundhir sembahyang merupakan suatu ibadah kepada tuhan yang maha esa. Tujuan dari laku sembahyang juga sama seperti yang dijelaskan di atas yaitu untuk berinteraksi dengan tuhan. Dalam prosesnya, laku sembahyang yang dilakukan Cak Mundhir bias dimana saja dan kapan saja. Selain itu, bentuk sembahyang bias berupa apa saja dalam artian laku sembahyang yang dilakukan bias dalam bentuk apa saja. Cak Mundhir pernah menuturkan bahwa sembahyang sepertihalnya ibadah kepada tuhan yang maha esa. Ibadah dalam hal ini bias berbentuk apa saja sepertihalnya yang dijelaskan sebelumnya terkait dengan kewajiban manusia. Seluruh aktivitas manusia menurut pandangan Cak Mundhir juga termasuk sembahyang dikarenakan apapun yang diterjadi dalam kehidupan manusia adalah kehendak tuhan dan menjalankan kehendak tuhan bias dikatakan sembahyang. Selain itu, sembahyang juga bias berupa sembahyang terhadap alam contohnya menyembah matahari, bumi, pohon dan juga yang lainnya. Sembahyang tersebut tidak bias diartikan menyembah matahari itu sendiri. Menurut pemaparan beliau semua yang ada di alam diartika sebagai sarana untuk bias secara langsung menyembah tuhan yang maha esa. Selain itu, pada dasarnya segala sesuatu yang ada di alam juga menyembah tuhan yang maha esa akan tetapi mereka mempunyai cara mereka sendiri untuk melakukannya. Pergerakan matahari dari barat ke timur juga diartikan oleh beliau sebagai bentuk cara matahari menyembah tuhan.

Laku sembahyang yang biasa dilakukan oleh Cak Mundhir adalah pada waktu beliau mau tidur. Pada saat tersebut beliau mewiridkan atau melafalkan nama tuhan sambil memejamkan mata. Dari situ, biasanya beliau mendapatkan petunjuk entah itu berupa anjuran, pengetahuan bahkan bayangan yang akan terjadi di masa depan pada saat bermimpi.

Sedangkan, kalau menurut pemaparan Mbah Khusein, laku sembahyang tidak dibatasi oleh waktu dan tempat. Kapanpun dan dimanapun beliau berada, beliau bias melakukan 
sembahyang. Bentuk laku sembahyang beliau berupa duduk bersila sambil memjamkan mata. Tujuan dari sembahyang juga sama halnya orang Aboge yang lainnya.

1. Praktek ritual bersama

Praktek ritual bersama biasanya dilakukan oleh orang Aboge yang sudah terorganisir atau komunal. Ritual bersama tersebut berupa kumpul-kumpul semua aliran kejawen di satu tempat yang sudah ditetapkan. Dalam hal ini, tempat kumpulnya menurut pemaparan Mas Jaka biasa dilaksanakan di pendopo agung di Troloyo, Jolotundo di trawas dan tempat-tempat lain yang dianggap keramat di daerah Mojokerto. Rata-rata tempat-tempat yang dijadikan kumpul-kumpul kebanyakan masih di daerah Mojokerto. Sedangkan untuk waktu pelaksanaannya biasanya dilakukan pada bulan Suro atau tepatnya tanggal satu Suro. Dan tujuan dari pelaksanaan ritual kumpul-kumpul bersama tersebut adalah untuk menyambut tahun baru Jawa yang dalam hal ini adalah bulan 1 Suro.

Bulan 1 Suro merupakan hari dan bulan keramat dalam pandangan orang Jawa. Menurut pemaparan beberapa orang kejawen bulan satu Suro merupakan bulan yang mana terdapat hari yang 7 jumlahnya (Saptawara), rangkapan pasaran yang berjumlah 5 (Pancawara), mangsa (Pranatamangsa) yang berjumlah 12, wuku yang berjumlah 30, Paringkelan yang berjumlah 6 (Sadwera), tahun yang berjumlah 8 dan windu yang berjumlah 4. Hal-hal tersebut merupakan perhitungan kalender yang ada di Jawa dan kalenderisasi tersebut seringkali dihubungkan dengan aktivitas-aktivitas mistis kejawen. Kalenderisasi tersebut jika dalam kalender nasional bias dinamakan dengan peerhitungan tahun, bulan, minggu dan juga hari.

Acara kumpul-kumpul tersebut berupa doa bersama serta makan-makan. Doa yang dilantunkan tidak sepenuhnya kejawen karena pada dasarnya doa-doa yang terdapat dalam aliran kejawen sudah tercampur dengan doa-doa yang berbau islam misalnya untuk penyebutan nama tuhan. Orang-orang Aboge tersebut menggunakan sebutan "gusti allah kang moho welas lan moho asih" (allah yang maha pengasih dan juga penyayang).

Dalam acara tersebut juga disiapkan semacam sesajen berupa kembang tujuh warna, air tujuh sumur, tumpeng, kemenyan, dupa dan lain-lain. Selain itu, istilah yang digunakan untuk menyebutkan hal-hal semacam itu pada waktu acara adalah "Skul Gondo Arum" (makanan berbau harum). Hal-hal tersebut menurut pemaparan dari bapaknya Mas Jaka diperuntukkan 
untuk memberikan jariyah atau istilah lainnya "sesambung" (penyambung) kepada para leluhur yang dulu-dulu karena mereka diundang untuk melakukan kenduren.

\section{Pandangan orang sekitar tentang Aboge}

Berbicara mengenai pandangan masyarakat umum tentang orang Aboge pada umumnya dapat diartikan sangatlah kompleks. Secara umum masyarakat yang ada di Jawa kebanyakan muslim akan tetapi keberadaan budaya dan tradisi yang di anut oleh masyarakat juga masih sangatlah kuat. Dengan demikian banyak kalangan masyarakat yang masih simpang siur ketika berbicara mengenai keberadaan orang Aboge. Pasalnya jika melihat dari kondisi keagamaan masyarakat Jawa dapat dikatakan bahwa agama masyarakat Jawa masih 50-50, dalam artian mereka tidak sepenuhnya islam dan tidak sepenuhnya Jawa. Oleh karena itu, ketika penelitian ini dilakukan, peneliti menemukan bahwa ada dua macam pandangan masyarakat terkait dengan keberadaan orang Aboge. Ada yang pro dan juga ada yang kontra terkait dengan keberadaan orang Aboge di dalam masyarkat. Pro dalam hal ini maksudnya adalah ada sebagian dari masyarakat yang tidak menentang dan tidak mempunyai perspective negative terhadap orangorang Aboge. Sedangkan, yang kontra adalah ada juga sebagian masyarakat yang mempunyai perspective negative terhadap keberadaan orang-orang tersebut dan tidak mau menerima keberadaan mereka.

Oleh karena itu, sebelum memasuki pembahasan antara yang pro dan kontra, penulis hendak memaparkan terlebih dahulu dimana dan bagaimana kondisi keagamaan masyarakat yang ada disekitar tempat orang-orang Aboge berada. Penelitian dilakukan tidak dalam satu tempat saja (desa) melainkan beberapa tempat yang ada di kabupaten Mojokerto. Pasalnya jumlah dari pada orang-orang tersebut bias dikatakan sangatlah sedikit dan tempatnya juga tidak saling berdekatan. Diantara tempat-tempat yang sudah peneliti datangi antara lain di desa Jabon Tegal kecamatan Pungging, Pulorejo, kutorejo, dlanggu, tanggulangin sidoarjo, tarik sidoarjo, gua putih trawas, pendopo agung-Troloyo-Mojokerto dan Jolotundo trawas. Di beberapa tempat tersebut bahkan ada yang mengasingkan diri tinggal di gua seperti halnya Mbah Khusein. Ada juga dari mereka yang tinggal di hutan daerah sekitar gunung welirang Mojokerto. Akan tetapi sayangnya untuk orang Aboge yang tinggal di hutan, peneliti tidak berhasil bertemu orang 
tersebut. Akan tetapi peneliti sedikit mendapatkan informasi mengenai orang tersebut. Dengan demikian untuk pembahasan lebih lanjut akan penulis bahas terkait pandangan masyarakat secara umum terkait dengan orang-orang Aboge.

Pada umumnya jika kita melihat keberadaan orang Aboge diukur dari segi agama mayoritas maka mereka akan memandang sebelah mata dalam artian mereka kurang sependapat dengan keberadaan orang Aboge dalam suatu masyarakat. Permasalahan yang diberatkan oleh masyarkat pada umumnya karena apa yang orang Aboge lakukan dan yakini seringkali bertentangan dengan ajaran agama yang masyarakat awam anut dalam hal ini adalah masyarakat muslim. Masyarakat muslim memandang orang-orang Aboge sebagai orang yang sesat dan tidak sejalan dengan ketentuan-ketentuan agama islam. Pandangan tersebut penulis asumsikan karena kebanyakan orang Aboge yang penulis temui secara kartu identitas, mereka beragama islam akan tetapi secara keyakinan mereka lebih kearah kejawen dari pada islam. Oleh karena itu, masyarakat awam menganggap mereka demikian.

Sepertihalnya yang diungkapkan oleh salah seorang guru ngaji dan juga imam sholat jum'at di daerah pesanggrahan Mojokerto. Penulis tidak bias menyebutkan nama dari sang informan karena beliau tidak mau namanya disebutkan dalam penulisan ini. Menurut perkataannya orang-orang Aboge yang menjalankan laku dan juga keyakinan kejawen dianggap sebagai orang musyrik dan sudah melenceng jauh dari ajaran agama. Perkataan tersebut didasari oleh pengalaman sang informan ketika mengetahui apa yang dilakukan dan diyakini orang-orang Aboge. Menurut pemaparannya praktek-praktek laku yang ada dalam ajaran kejawen seperti puasa pati geni, puasa kalong, dan ngembong bukanlah hal-hal yang diajarkan oleh nabi Muhammad dan tidak pula disyariatkan dalam agama islam. Selain itu, laku-laku seperti pemujaan terhadap roh-roh leluhur dan juga alam yang kesemuanya berbau mistis merupakan salah satu bentuk kemusyrikan. Oleh karena itu, beliau bahkan menegaskan bahwasanya hal-hal tersebut hendaklah segera diberikan pencerahan ulang tentang ajaran yang benar yang menrujuk pada ajaran islam.

Penuturan lain yang juga kontra terhadap ajaran kejawen orang Aboge adalah Mas Faiz. Mas faiz adalah penduduk local yang tinggal di daerah sekitaran pinggiran kota Mojokerto. Dia pemuda berumur 27 tahun yang dulunya juga sering mengunjungi bahkan mengikuti ritual-ritual kejawen di daerah Mojokerto. Menurut penuturannya orang yang melakukan laku-laku ritual 
kejawen ada yang sudah melenceng jauh dari ajaran kebenaran dan ada juga yang sama dengan ajaran islam. Dia menganggap bahwa orang-orang yang melakukan laku kejawen seperti ritualritual di pemakaman dan ritual di tempat-tempat keramat sudah jauh dari kebenaran. Pasalnya mereka percaya kepada kekuatan lain selain kekuatan Allah yaitu kekuatan jin dan lain-lain. Selain itu, pelaku ritual juga menggunakan kemenyan, dupa dan sesajian-sesajian yang sudah tidak selaras lagi dengan ajaran yang sudah di ajarkan agama islam. Untuk orang-orang Aboge yang semacam itu, dia menganggapnya sebagai orang-orang sesat. Dia memberikan contoh sebagai salah satu yang sudah melenceng dari kebenaran yaitu dukun-dukun yang menggunakan ilmu hitam dan jin untuk memperlancar urusannya. Akan tetapi orang-orang Aboge yang tidak menggunakan jin dan benar-benar percaya bahwa hanya ada tuhan menurut pandangannya adalah orang-orang ngerti.

Ada juga seorang ibu yang tinggal di Mojokerto, beliau adalah pemilik warung kopi di daerah trawas dan kebetulan warungnya tidak jauh dari tempatnya Mbah Khusein atau gua putih. Jarak antara warungnya dan gua putih sekitar $1 \mathrm{~km}$. Menurut pemaparannya ketika peneliti wawancarai terkait dengan keberadaan orang Aboge tersebut beliau menJawab tidak tahu apaapa mengenai apa kegiatan dari Mbah Khusein itu sendiri. Beliau hanya tahu bahwa Mbah Khusein dianggap seperti orang yang tidak bertanggung Jawab terhadap keluarganya karena apa yang sudah dilakukannya adalah meninggalkan keluarga dan melarikan diri dari tanggung Jawab. Beliau memaparkan bahwa keluarganya sudah cerai berai dan bahkan anaknya tidak mau mengurusi orang tua tersebut. Dari cerita tersebut dapat dikatakan bahwasanya ada perspective negative yang melekat kepada orang Aboge dalam pandangan masyarakat awam di daerah tersebut.

Selain itu, ada yang mengatakan bahwa laku atau ajaran yang diyakini oleh orang Aboge adalah ajaran yang sesat dan gila. Seperti yang diungkapkan oleh Mas Irul salah satu penduduk daerah kutorejo. Dia adalah pekerja swasta di daerah tersebut dan dia juga sedikit mengerti tentang ajaran kejawen. Sebelumnya dia tidak mengakui bahwasanya apa yang dikatakan oleh orang Aboge merupakan suatu yang benar dalam artian apa yang dikatakan oleh orang Aboge adalah menyimpang dari ajaran islam pada umumnya. Selain itu, dia menganggap orang yang mendalami ajaran kejawen orang Aboge adalah orang gila. Salah satu pengalaman yang dia pernah alami adalah pada saat orang Aboge yang bersangkutan berbicara kepadanya terkait 
dengan kehidupan setelah mati. Menurut pemaparan orang Aboge bahwa "setalah kita mati kita akan hidup kembali setelah itu datang dua orang yang mirip sekali dengan kita dan mereka akan menyiksa kita". Dalam pandangan Mas Irul waktu itu, "ketika orang mati, orang akan dibangkitkan kembali, kemudian dibangkitkan dan diadili oleh malaikat tergantung amalnya". Hal tersebut sangatlah berbeda dengan ajaran yang Mas Irul terima sehingga pada waktu itu Mas Irul menganggap apa yang sudah diomongkan merupakan hal-hal gila dan yang mengatakan hal tersebut juga gila. Akan tetapi setelah satu tahun baru Mas Irul sadar bahwa yang diomongkan oleh orang Aboge tersebut adalah benar setelah mempelajari maksudnya secara mendalam.

Pandangan negative lain juga dipaparkan oleh salah seorang ibu rumah tangga yang bias dikatakan bahwa dia juga mempunyai paham fanatic islam. Beliau tidak mau disebutkan namanya dalam penelitian ini secara penuh oleh karena itu di sini akan disebutkan initial namanya saja. Initial huruf yang digunakan adalah $\mathbf{M}$. Ibu $\mathbf{M}$ adalah masih punya hubungan keluarga dengan salah seorang Aboge di daerang Pungging. Orang Aboge tersebut adalah keponakan dari ibu M. Menurut ibu M, keponakannya itu sudah dikategorikan sebagai orang gila karena apa yang sudah dilakukan merupakan hal yang sama dengan orang gila bahkan bukan hanya ibu M tetapi juga family yang juga beranggapan sama, dia menjelaskan secara detail bahwa keponakannya tersebut sudah tidak pernah sholat ataupun menjalankan praktek-praktek agama islam yang dianutnya malahan menjalankan praktek laku yang tidak masuk akal. Meskipun demikian ibu M juga mengakui bahwasanya keponakannya tersebut bukanlah orang sembarangan dalam artian sama halnya dengan orang suci.

Sebenarnya ada beberapa lagi pendapat orang terkait dengan pandangan negative terhadap orang Aboge. Akan tetapi untuk mempersingkatnya saya mengambil yang singkatsingkat sepertihalnya pendapat yang diutarakan oleh beberapa orang diatas. Dilihat dari background yang saya wawancarai ada yang dari mereka pernah belajar di pesantren, orang awam, ibu-ibu ngaji dan juga pekerja pabrik. Mereka adalah orang-orang yang mempunyai background keislaman yang cukup kuat dan ada juga yang mempunyai pemahaman terkait dengan keislaman dan kejawen. Demikian menurut pendapat orang-orang yang kontra dengan keberadaan orang-orang Aboge. Dan berikut ini pandangan yang pro terhadap keberadaan orang Aboge. 
Salah satu pendapat yang sifatnya sangat toleran dengan keberagaman masyarakat indonesia adalah bapak solikin. Beliau adalah seorang kepala desa Jabon Tegal kecamatan Pungging yang baru dilantik pada tahun 2013. Menurut beliau keberadaan aliran kejawen di indonesia khususnya di daerah Mojokerto bukanlah hal yang harus dipermaslahkan dalam artian mereka bukan masalah bagi kehidupan social masyarakat. Beliau tidak mempermasalahkan apapun tentang laku para pemeluk ajaran kejawen ataupun keyakinan yang dimiliki orang-orang tersebut. Karena pada hakikatnya, mereka juga sama seperti ajaran islam yaitu menyembah kepada tuhan yang maha esa. Dan beliau juga sangat menghargai keberadaan mereka bukan hanya sebagai tradisi atau budaya akan tetapi juga sebagai penganut berkeyakinan. Beliau juga memaparkan ketika peneliti bertanya "apa anda tidak takut kalau-kalau orang-orang tersebut membawa dampak buruk terhadap ajaran agama islam di daerah sini”, kemudian beliau menJawab "pada dasarnya sebuah keyakinan itu tergantung orangnya dan saya yakin keyakinan yang mereka anut tidak ada maksud apapun apalagi membuat huru-hara di kampong ini”. Dalam artian, apa yang diungkapkan oleh pak solikin terkait dengan keberadaan Aboge tidaklah berkesan negative.

Pendapat lain yang hamper sama juga di ungkapkan oleh Mas Samsul, beliau adalah seorang beragama islam dan juga bapak rumah tangga di daerah Pulorejo Mojokerto. Menurut pemaparan beliau pada hakikatnya ajaran kejawen yang dianut oleh orang Aboge tersebut merupakan ajaran yang sama dengan ajaran islam. Secara syariat mungkin berbeda tapi secara hakikat semuanya sama. Apa yang mereka lakukan adalah sebagai bentuk keyakinan mereka, selain itu, apa yang mereka lakukan juga tidak sampai dengan mengganggu orang beragama lain. Bahkan ajaran kejawen orang Aboge menurut beliau adalah sesungguhnya ajaran yang benar. Karena dalam ajaran tersebut manusia bias mengenal sejatinya manusia itu sendiri dan sejatinya tuhannya.

Jika Mas Samsul mengatakan ajaran kejawen orang Aboge adalah ajaran yang sebenarnya ajaran, maka hal tersebut berbeda dengan apa yang dikatakan oleh Cak Andhim. Cak Andhim adalah juga orang islam yang taat dan juga mengetahui pemahaman tentang ajaran kejawen yang cukup luas. Menurut beliau ajaran islam dan ajaran kejawen hakikatnya sama. Tidak ada yang berbeda secara hakikat. Sedangkan praktek-praktek laku kejawen yang sifatnya supernatural ataupun kesaktian, sebenarnya hal tersebut bukanlah ajaran inti dari ajaran kejawen 
karena ajaran kejawen lebih mengarah kepada hakikat ketuhanan atau dalam islam disebut tauhid.

Pendapat yang sama juga dituturkan oleh Pak Budi, seorang kakek yang sudah berumur cukup sepuh dan juga seorang anggota militer dulunya. Beliau mengatakan bahwa "ajaran kejawen adalah ajaran asli orang Jawa, mereka tidak sseharusnya dipandang sebelah mata oleh orang lain karena pada dasarnya mereka adalah orang yang lebih mengerti tentang Jawa dibandingkan dengan orang-orang islam di Jawa”. Beliau meneruskan bahwasanya orang-orang laku kejawen lebih mengerti sejatinya dirinya dari pada tokoh-tokoh agama jaman sekarang. Pasalnya, tokoh-tokoh agama zaman sekarang lebih mementingkan duniawi dari pada mendekatkan diri kepada tuhan.

Demikian pemaparan dari beberapa orang yang sudah peneliti wawancarai. Sebagian dari mereka adalah orang yang paham sekali dengan ajaran islam dan kejawen sepertihalnya Cak Andhim karena dulu beliau juga sempat belajar ilmu kejawen dan juga sempat belajar di pondok pesantren.

Dalam pandangan penulis, penulis menyimpulkan bahwasanya ada dua macam orang islam dilihat dari pro dan kontra tentang orang Aboge. Pertama adalah penganut islam fanatic dalam artian mereka tidak setuju dengan adanya praktek laku dan keyakinan yang dianut oleh orang Aboge karena sudah dianggap jauh menyimpang dari ajaran islam. Dan kedua adalah islam yang tidak fanatic dalam artian mereka tidak memandang sebelah mata atau negative terkait keberadaan orang Aboge karena menurut pemahaman mereka ajaran yang orang Aboge anut tidaklah sebetulnya menyimpang dari hakikat ajaran islam. 


\section{DAFTAR INFORMAN}

Cak Mundir : Penghayat Aboge

Cak Andhim : Seorang warga desa kutorejo dengan banyak pengetahuan tentang ilmuilmu dan filosofi jawa atau kejawenan

Mas Jaka : : Penghayat kelompok Roso Sejati

Mbah Khusein : : Seorang penghayat kepercayaan yang tinggal di gua selama puluhan tahun berlokasi di desa sumber glagah kecamatan trawas kabupaten Mojokerto. 